\title{
Keefektifan Model Group Investigation Materi Keliling dan Luas Bangun Datar Terhadap Hasil Belajar
}

\author{
Candra Rossyani Wijayanto ${ }^{1}$, Sutrisno ${ }^{2}$, Qoriati Mushafanah ${ }^{3}$ \\ 1,2,3 Jurusan Pendidikan Guru Sekolah Dasar, Universitas PGRI Semarang \\ e-mail: candrac689@gmail.com
}

\begin{abstract}
Abstrak
Penelitian ini bertujuan untuk menguji keefektifan model Group Investigation terhadap hasil belajar siswa pada pembelajaran matematika materi keliling dan luas bangun datar kelas IV di Sekolah Dasar. Metode penelitian ini yang digunakan adalah metode eksperimen semu dengan rancangan penelitian yang digunakan adalah pre experimental design. Design penelitian menggunakan pre experimental design one group pretest-posttest design..Sampel dalam penelitian ini adalah 32 peserta didik. Hasil analisis data menunjukkan bahwa hasil belajar peserta didik pada postest di kelas eksperimen efektif digunakan sebesar 0,1297 . Hal ini berarti pembelajaran dengan menerapkan model Group Investigation efektif dengan kriteria tinggi terhadap hasil belajar peserta didik kelas IV dalam pembelajaran Matematika Materi Keliling dan Luas Bangun Datar di SD N 1 Sukodadi.
\end{abstract}

Kata Kunci: Group Investigation, Hasil Belajar

\begin{abstract}
This study aims to test the effectiveness of the group investigation model on student learning outcomes in material mathematics learning around the area and the flat building area of class IV in elementary school. This research method used is a quasi-experimental method with the research design used is a pre-experimental design. The design of the study used preexperimental design one group pretest-posttest design. The sample in this study was 32 students. The results of data analysis showed that the learning outcomes of students in the posttest in the experimental class were effectively used at 0,1297. This means learning by applying an effective investigation group model with high criteria towards learning outcomes of fourth-grade students in learning mathematics around the material and the area of the flat building in SD N 1 Sukodadi.
\end{abstract}

Keywords: Group Investigation, learning outcomes 


\section{Pendahuluan}

Pendidikan adalah pengaruh lingkungan atas individu untuk menghasilkan perubahanperubahan yang tetap (permanen) didalam kebiasaan-kebiasaan tingkah lakunya, pikiranya, dan sikapnya. Undang-undang No. 20 Tahun 2003 Tentang Sistem Pendidikan Nasional menyatakan bahwa, pendidikan adalah usaha sadar dan terencana untuk mewujudkan suasana belajar dan proses pembelajaran agar peserta didik secara aktif mengembangkan potensi dirinya untuk memiliki kekuatan spiritual keagamaan, pengendalian diri, kepribadian, kecerdasan, akhlak mulia, serta keterampilan yang diperlukan dirinya, masyarakat, bangsa dan Negara. Dalam hal ini proses pembelajaran di dalam kelas harus memperhatikan komponenkomponen belajar mengajarnya. Menurut Djamarah dan Aswan (2010:41), komponenkomponen belajar mengajar meliputi tujuan, bahan pelajaran, kegiatan belajar mengajar, metode, model, alat dan sumber serta evaluasi.

Proses Pembelajaran yang optimal membutuhkan komponen-komponen pendukung. Salah satunya adalah model pembelajaran. Model pembelajaran merupakan rancangan yang disusun dengan tujuan untuk meningkatkan kualitas sebuah pembelajaran. Ada berbagai model pembelajaran, salah satunya adalah model Group Investigation. Ide model pembelajaran Group Investigation bermula dari prespektif filosofis terhadap konsep belajar. Untuk dapat belajar, seseorang harus memiliki pasangan atau teman.Pada tahun 1916, John Dewey, menulis sebuah buku, dalam buku itu Dewey menggagas konsep pendidikan. Dan gagasan-gagasan Dewey dikembangkan oleh Herbert Thelen. Thelen menyatakan bahwa kelas hendaknya merupakan miniature demokrasi yang bertujuan mengkaji masalah-masalah sosial antar pribadi (Darmadi, 2017:131). Karakteristik siswa yang senang berhubungan langsung dan mengaitkan berbagai hal dengan kehidupan nyata sangat tepat bila dilakukan dengan penanaman konsep dengan melibatkan temannya untuk dapat diajak berdiskusi dalam memecahkan masalah. Model pembelajaran Group Investigation ini mengutamakan peran siswa dalam pembelajaran dan kerjasama kelompok secara heterogen dapat menarik perhatian dan meningkatkan semangat belajar siswa.

Sedangkan belajar adalah suatu proses usaha yang dilakukan seseorang untuk memperoleh perubahan tingkah laku yang baru secara keseluruhan, sebagai hasil pengalamannya sendiri dalam interaksi dengan lingkungannya (Slameto, 2013:2). Dari hal tersebut dapat kita ketahui bahwa proses belajar terlaksana karena adanya interaksi. Belajar adalah suatu aktivitas atau suatu proses untuk memperoleh pengetahuan, meningkatkan keterampilan, memperbaiki perilaku, sikap, dan mengokohkan kepribadian. Proses belajar merupakan bagian dari pendidikan yang disebutkan dalam undang-undang Nomor 20 Tahun 2003 tentang Sistem Pendidikan pasal 1 adalah usaha sadar dan terencana untuk mewujudkan suasana belajar dan proses pembelajaran agar peserta didik secara aktif mengembangkan potensi dirinya untuk memiliki kekuatan spiritual keagamaan, pengendalian diri, kepribadian, kecerdasan, akhlak mulia serta keterampilan yang diperlukan dirinya, masyarakat, bangsa dan Negara (Depdiknas, 2003:1).

Matematika adalah ilmu tentang struktur yang terorganisasi mulai dari unsur yang tidak didefinisikan, ke unsur yang didefinisikan, ke aksioma atau postulat, dan akhirnya ke dalil. Pendapat dari Johnson dan Rising mengungkapkan bahwa matematika adalah bahasa yang didefinisikan dengan cermat, jelas, akurat representasinya menggunakan simbol.Selain itu, Kline berpendapat bahwa matematika bukan pengetahuan tersendiri yang dapat sempurna karena dirinya sendiri, tetapi adanya matematika itu untuk membantu manusia dalam menguasai permasalahan sosial, ekonomi, dan alam.(Isrok'atun, 2018:3).

Proses pembelajaran yang berlangsung umumnya masih menggunakan metode ceramah, dimana guru menerangkan materi dan siswa hanya mendengarkan serta mencatat saja, sehingga keaktifan dalam pembelajaran tidak ada. Penggunaan metode dan model pembelajaran oleh seorang guru sangat berpengaruh dalam keaktifan belajar siswa. Seorang guru dapat menggunakan berbagai model atau metode mengajar untuk mencapai tujuan pengajaran, dimana metode atau model pembelajaran yang dipakai dapat menarik perhatian siswa sehingga dapat meningkatkan keaktifan dan hasil belajar siswa dalam proses pembelajaran.

Selain itu, apabila proses pembelajaran yang diterapkan oleh guru masih kurang menarik, maka mengakibatkan siswa tidak terlibat sama sekali saat proses belajar mengajar berlangsung. Akibatnya, banyak siswa yang terlihat malas saat pembelajaran tersebut,sehingga saat adanya evaluasi, siswa kurang percaya diri dalam mengerjakan soal-soal evaluasi dan hasil belajar kurang memuaskan. 
Model pembelajaran merupakan salah satu komponen pembelajaran yang menjadi panduan dalam melakukan langkah-langkah kegiatan. Dalam mengaplikasikan langkah-langkah model pembelajaran terdapat pendekatan, strategi, metode, teknik, dan taktik yang digunakan guru untuk menunjang pembelajaran. Sementara itu, model pembelajaran merupakan wadah dalam melakukan segala bentuk kegiatan belajar untuk mencapai tujuan pembelajaran.(Isrok'atun, 2018:26).

Fungsi model pembelajaran adalah sebagai pedoman bagi pengajar dan para guru dalam meaksanakan pembelajaran. Hal ini menunjukaan bahwa setiap model yang akan digunakan dalam pembelajaran menentukan perangkat yang dipakai dalam pembelajaran tersebut.

Metode Group Investigation (GI) yang pertama kali di kembangkan oleh sharan dan Sharan (1976) ini merupakan salah satu metode kompleks dalam pembelajaran kelompok yang mengharuskan siswa untuk menggunakan skill berpikir level tinggi. dalam penggunaan model Group Investigation, setiap kelompok akan bekerja melakukan investigasi sesuai dengan masalah yang mereka pilih. Sesuai dengan pengertian-pengertian tersebut, diketahui bahwa model Group Investigation adalah pembelajaran yang melibatkan aktifitas siswa sehingga tentu akan membangkitkan semangat serta motivasi mereka untuk belajar.

Menurut Grimison dan Dawe, istilah investigasi dalam pembelajaran matematika pertama kali dikemukakan oleh Commite of Inquiry into The Teaching of Mathematics in School dalam Cockroft Report tahun 1982. Dalam laporan tersebut direkomendasikan bahwa pembelajaran matematika dalam setiap jenjang pendidikan harus meliputi : a). Eksposisi (pemaparan guru); b) diskusi antar guru dengan siswa serta antar siswa sendiri; c) kerja praktis; d) pemantapan dan latihan kemampuan dasar atau soal; e) pemecahan masalah; f) kegiatan investigasi.(Isrok'atun, 2018:111).

Investigasi matematika sebagai proses penyelidikan yang terkait dengan masalah dalam bidang matematika. Berikut ini beberapa pandangan mengenai investigasi matematika. Singapore Ministry of Education, menyatakan bahwa investigasi matematika adalah suatu aktifitas matematika yang divergen. Investigasi matematika memberikan kesempatan kepada siswa untuk bekerja dalam situasi matematika yang terbuka. Menurut Batow, investigasi matematika merupakan suatu pendekatan pembelajaran yang dapat mendorong suatu aktifitas percobaan, mengumpulkan data, melakukan observasi, mengidentifikasi suatu pola, membuat dan menguji kesimpulan/dugaan, dan dapat pula sampai membuat suatu generalisasi. Dengan demikian menjadi topik pembelajaran, untuk melakukan identifikasi dan penyelesaian masalah. (Isrok'atun, 2018:111).

Variabel Penelitian

Variabel penelitian adalah segala sesuatu yang ditetapkan oleh peneliti untuk dipelajari sehingga diperoleh informasi tentang hal tersebut, kemudian ditarik kesimpulannya (Sugiyono, 2017:60). Terdapat 2 (dua) jenis variabel yang digunakan dalam penelitianini yaitu variabel bebas (independent variabel)dan variabel terikat (dependent variable). Terdapat dua Variabel dalam penelitian ini, yaitu variabel independen (bebas) dan variabel dependen (terikat). Model pembelajaran Group Investigation dalam penelitian ini merupakan variabel bebas yang di lambangkan dengan $(X)$, sedangkan variabel terikat dilambangkan dengan $(Y)$ dalam penelitian ini adalah hasil belajar siswa kelas IV SDN 1 Sukodadi

\section{Metode}

Metode yang digunakan peneliti dalam penelitian ini menggunakan pendekatan Kuantitatif. Sedangkan metode penelitian yang digunakan adalah metode eksperimen. Metode penelitian ini menggunakan preexperimental design. Desain penelitian ini menggunakan pre experimental design one group pretest-posttest design dengan subyek penelitian hanya menggunakan satu kelas. Hanya menggunakan kelas eksperimen tanpa menggunakan kelas kontrol. Peneliti akan membandingkan nilai pretest dan posttest siswa sebelum dan sesudah diberi perlakuan dalam kegiatan pembelajaran dengan menggunakan model Group Investigation.

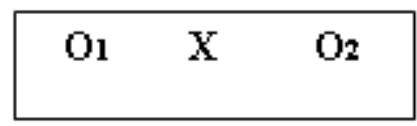

Gambar 1. Desain Penelitian Pre Experimental Design 
Keterangan

O1 :Tes awal sebelum adanya perlakuan

O2 : Tes akhir sesudah adanya perlakuan

$\mathrm{X} \quad$ : Perlakuan dengan Group Investigation

Dalam penelitian ini, kelas diberi pretest untuk mengetahui kondisi awal kemampuan hasil belajar sebelum adanya perlakuan, kemudian kelas diberi perlakuan dengan Group Investigation. Selanjutnya diberi posttest sesudah diberi perlakuan untuk mengetahui ada tidaknya perubahan terhadap hasil belajar siswa. Berikut tabel rancangan desain penelitian.

Tabel 1. Rancangan desain One Group Pretest-posttest Design

\begin{tabular}{cccc}
\hline Kelompok & Tes & Perlakuan & Tes \\
\hline Kelas IV & Pretest & $\begin{array}{c}\text { Pembelajaran Model Grup } \\
\text { Investigation }\end{array}$ & Posttest \\
\hline
\end{tabular}

Teknik Pengumpulan data

Populasi adalah wilayah generalisasi yang terdiri atas objek/subjek yang mempunyai kualitas dan karakteristik tertentu yang ditetapkan oleh peneliti untuk dipelajari dan kemudian ditarik kesimpulannya (Sugiyono, 2017:117). Dalam penelitian ini peneliti mengambil siswa kelas IV SDN 1 Sukodadi sebagai populasi. Dalam penelitian ini proses pengambilan sampel menggunakan teknik sampling jenuh. Karena sampling jenuh meggunakan teknik penentuan sampel semua anggota populasi digunakan sebagai sampel (Sugiyono, 2017: 124).

a) Tes

Tes adalah alat atau prosedur yang digunakan untuk mengetahui atau mengukur sesuatu dalam suasana, dengan cara dan aturan-aturan yang sudah ditentukan. (Arikunto, 2010:67). Tes terutama tes kepribadian banyak yang bersifat deskriptif, tetapi deskripsinya mengarah kepada karakteristik atau kualifikasi tertentu sehingga mirip dengan interpretasi dari hasil pengukuran. Tes yang digunakan dalam pendidikan biasa dibedakan antara tes hasil belajar (achievement tests) dan tes psikologis (psychological tests) ( Sukmadinata, umumnya mengukur, walaupun beberapa bentuk tes psikologis 2010: 223).

b) Observasi

Observasi (observation) atau pengamatan merupakan suatu teknik atau cara mengumpulkan data dengan jalan mengadakan pengamatan terhadap kegiatan yang sedang berlangsung. Kegiatan tersebut bisa berkenaan dengan cara guru mengajar, siswa belajar, kepala sekolah yang sedang memberikan pengarahan, personil bidang kepegawaian yang sedang rapat, dsb. Observasi dapat dilakaukan secara partisipatif ataupun nonpartisipatif (Sukmadinata, 2010: 220). Pada penelitian ini peneliti menggunakan observasi partisipan yang terlibat dalam proses pembelajaran.

c) Dokumentasi

Dokumentasi merupakan catatan peristiwa yang sudah berlalu. Dokumen bisa berbentuk tulisan, gambar atau karya-karya monumental dari seseorang (Sugiyono, 2012 :329).

Instrument Penelitian

Dalam penelitian ini data-data dikumpulkan melalui catatan dan pengamatan dari guru.

Pengumpulan data tersebut dilakukan dengan menggunakan instrumen sebagai berikut :

a) Uji Validitas

Instrument yang valid berarti alat ukur yang digunakan untuk mendapatkan data (megukur) itu valid. Valid berarti instrumen tersebut dapat digunakan untuk mengukur apa yang searusnya diukur (Sugiyono, 2017:173) untuk menghitung validitas diperlukan rumus korelasi product momen :

$$
\mathrm{rxy}=\frac{\mathrm{N} \sum X Y-\left(\sum X\right)\left(\sum Y\right)}{\left.\sqrt{\left\{N \sum X^{2}\right.}-\left(\sum X\right)^{2}\right\}\left\{N \sum Y^{2}-\left(\sum Y\right)^{2}\right\}}
$$


keterangan

$\begin{array}{ll}r_{x y} & : \text { Koefisien korelasi antar } x \text { dan } y \\ N & : \text { Jumlah siswa yang di teliti } \\ \Sigma X & : \text { Skor tiap butir soal } \\ \Sigma Y & : \text { Skor total }\end{array}$

Harga $r_{x y}$ yang di peroleh dibanding dengan $r_{\text {tabel }}$ product moment dengan taraf signifikan $5 \%$ jika harga $r_{\text {hitung }}>r_{\text {tabel }}$ maka butir soal dinyatakan valid tetapi jika $r_{\text {hitung }} \leq r_{\text {tabel }}$ maka butir soal dinyatakan tidak valid. Hasil yang diperoleh kemudian diinterpretasikan menurut aturan sebagai berikut:

Antara 0,800 sampai dengan $1,00=$ Sangat tinggi

Antara 0,600 sampai dengan $0,800=$ Tinggi

Antara 0,400 sampai dengan $0,600=$ Cukup

Antara 0,200 sampai dengan $0,400=$ Rendah

Antara 0,00 sampai dengan $0,200=$ Sangat rendah

Dalam perhitungan uji coba kriteria kevaliditasan suatu soal dengan taraf signifikan $5 \%$ yaitu 0,444 dapat ditentukan jika : $r_{\text {hitung }}>r_{\text {tabel }}$ maka butir soal dikatakan valid. Rekap data hasil uji coba validitas soal uji coba dapat dilihat pada Tabel 2 sebagai berikut :

Tabel 2. Uji Validitas Uji Coba

\begin{tabular}{l|l}
\hline & Nomor Soal \\
\hline Valid & $2,, 3,4,6,9,11,12,13,16,17,18,20,21,23,24,25,27,28.29$, \\
& $32,34,37,39$. \\
\hline Tidak Valid & $21,5,7,8,10,14,15,19,22,26,30,31,33,35,36,38,40$ \\
\hline
\end{tabular}

Berdasarkan Tabel 2 dapat diketahui bahwa dari 40 soal yang diuji cobakan yang bersifat valid adalah nomor soal 2, ,3, 4, 6, 9, 11, 12, 13, 16, 17, 18, 20, 21, 23, 24, 25, 27, 28. $29,32,34,37,39$. Sedangkan yang bersifat tidak valid adalah nomor soal 1, 5, 7, 8, 10, 14, 15, $19,22,26,30,31,33,35,36,38,40$. Sehingga dari 40 butir soal uji coba ada 23 butir soal yang memenuhi kriteria validitas. Data selengkapnya dapat dilihat pada lampiran.

b) Uji Reliabilitas

Reliabel digunakan untuk mengukur berkali-kali menghasilkan data yang sama (konsisten) (Sugiyono, 2017:186). Rumus yang digunakan untuk mencari reliabilitas yaitu menggunakan rumus K-R.20 sebagai berikut.

$$
r_{11}=\left(\frac{n}{n-1}\right)\left(\frac{S^{2}-\sum p q}{S^{2}}\right)
$$

Dengan $S^{2}=\frac{\Sigma y^{2} \frac{(\Sigma Y)^{2}}{N}}{N}$

Keterngan :

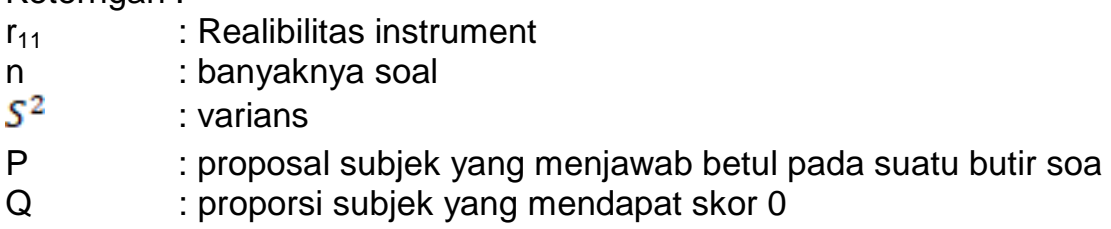

Setelah $r_{11}$ ditemukan, kemudian dengan dibandingkan dengan harga $r_{\text {tabel }}$ Apabila $r_{11}>r_{\text {tabel }}$ maka instrument dikatakan reliable. Kriteria reliabelitas adalah sebagai berikut :

$\begin{array}{ll}0,800<r_{11} \leq 1,00 & =\text { reliabilitas sangat tinggi } \\ 0,600 \leq r_{11}<0,800 & =\text { reliabilitas tinggi } \\ 0,400 \leq r_{11}<0,600 & =\text { reliabilitas cukup } \\ 0,200 \leq r_{11}<0,400 & =\text { reliabilitas rendah } \\ 0,000 \leq r_{11} \quad 0,200 & =\text { reliabilitas sangat rendah }\end{array}$


Setelah diperoleh harga $r_{11}$ kemudian di bandingkan dengan $r_{\text {tabel }}$ product moment dengan $\alpha=5 \%$. Instrument dikatakan reliabel jika $r_{11}>r_{\text {tabel. }}$ Rekap data hasil uji reabilitas soal uji coba dapat dilihat pada tabel 3.4 sebagai berikut :

Tabel 3. Hasil Uji Reliabilitas

\begin{tabular}{cc}
\hline KR-20 & K \\
\hline 0,859264996 & 40 \\
\hline
\end{tabular}

Dengan melihat nilai pada kolom KR20, kita dapat menentukan reliabel tidaknya suatu instrumen. Hasil uji reliabilitas menunjukan nilai sebesar 0,859264996 , sehingga instrumen soal sudah terbukti reliabel dan termasuk klasifikasi sangat tinggi.

c) Daya Pembeda

Daya pembeda memiliki arti seberapa jauh butir soal mampu membedakan kemampuan dari tiap siswa. Rumus untuk menghitung daya pembeda sebagai berikut :

$$
D=\frac{B A}{J A}-\frac{B B}{J B}=\mathrm{P}_{\mathrm{A}}-\mathrm{P}_{\mathrm{B}}
$$

Keterangan :

D : Daya pembeda (indeks diskriminasi)

J : Jumlah peserta tes

$J_{A} \quad$ : Banyaknya peserta kelompok atas

$J_{B} \quad$ : Banyaknya Peserta kelompok bawah

$\mathrm{B}_{\mathrm{A}} \quad$ : Banyaknya peserta kelompok atas yang menjawab soal itu dengan benar

$B_{B} \quad$ : Banyaknya peserta kelompok bawah yang menjawab soal itu benar

Klasifikasi daya pembeda

$$
\begin{array}{lll}
\text { D } & : 0,00-0,20 & =\text { JELEK } \\
\text { D } & : 0,21-0,40 & =\text { CUKUP } \\
\text { D } & : 0,41-0,70 & =\text { BAIK } \\
\text { D } & : 0,71-1,00 & \text { BAIK SEKALI }
\end{array}
$$

Daya hasil uji daya beda soal uji coba dapat dilihat pada tabel 3.4 berikut

Tabel 4. Hasil Uji Daya Beda Tes Soal Uji Coba

\begin{tabular}{l|c}
\hline \multicolumn{1}{c|}{ Nomor Soal } & Daya Beda \\
\hline $3,4,6,9,11,12,13,17,21,24,25,27,28,29,34,39$ & Baik \\
\hline $1,2,5,7,8,10,14,15,16,18,20,22,23,26,30,31,32,33,35,36,37,38$, & Buruk \\
40. & \\
\hline
\end{tabular}

Tabel 4 diatas menunjukan bahwa terdapat 16 soal dengan daya pembeda baik, 24 soal dengan daya pembeda buruk.

d) Tingkat Kesukaran

Menurut Taraf kesukaran soal dianalisis guru mengetahui tingkat kesukaran pada tiap butir soal. Taraf kesukaran dilihat dari kemampuan siswa dalam menjawab tiap butir soal, taraf kesukaran dianalisis setelah dilakukan tes uji coba instrument. Perhitungan taraf kesukaran dilakukan dengan bantuan program Microsoft excel 2010. Rumus :

$$
\mathrm{P}=\frac{B}{I s}
$$

Keterangan :

P $\quad$ : indeks kesukaran

B : banyaknya siswa yang menjawab soal betul

JS : jumlah seluruh peserta tes 
Tabel 5. Klarifikasi Taraf Kesukaran :

$\begin{array}{ll}\text { Taraf Kesukaran } & \text { Kriteria } \\ 0,00 \leq P \leq 0,30 & \text { Sukar } \\ 0,30 \leq P \leq 0,70 & \text { Sedang } \\ 0,70 \leq P \leq 1,00 & \text { Mudah }\end{array}$

Data hasil uji taraf kesukaran soal uji coba dapat dilihat pada tabel 3.5 sebagai berikut :

Tabel 6. Taraf Kesukaran Tes Soal Uji Coba

\begin{tabular}{c|c}
\hline Nomor Soal & $\begin{array}{l}\text { Taraf } \\
\text { Kesukaran }\end{array}$ \\
\hline $30,31,33,35$ & Sukar \\
\hline $2,3,6,8,11,12,14,17,19,22,26,27,28,29,34,39,40$ & Sedang \\
\hline $2,3,6,8,11,12,14,17,19,22,26,27,28,29,34,39,40$ & Mudah \\
\hline
\end{tabular}

Berdasarkan Tabel 5 dari 40 soal uji coba terdapat 4 soal yang termasuk dalam kategori taraf kesukaran sukar yaitu pada nomor soal $30,31,33,35$. Untuk soal dengan kategori taraf kesukaran sedang yaitu pada nomor 2, 3, 6, 8, 11, 12, 14, 17, 19, 22, 26, 27, 28, 29, 34, 39, 40. Dan untuk kategori taraf kesukaran mudah 1, 4, 5, 7, 9, 10, 13, 15, 16, 18, 20, $21,23,24,25,32,36,37,38$.

\section{Metode Analisis Data}

1. Analisis Data Awal

a. Uji Normalitas

Uji Uji Normalitas sampel digunakan untuk mengetahui apakah hasil belajar siswa pada suatu kelas yaitu hasil belajar pada kelas eksperimen berdistribusi normal atau tidak.

$H_{0}$ : sampel berasal dari populasi yang berdistribusi normal

$H_{a}$ : sampel berasal dari populasi yang berdistribusi tidak normal.

Langkah-langkahnya :

1) Hasil pengamatan $x_{1} x_{2}, x_{3}, \ldots \ldots, x_{n}$ diubah dalam bilangan buku dalam $z_{1}, z_{2}, z_{3}, \ldots, \ldots, z_{n}$ dengan menggunakan rumus :

$$
Z_{1}=\frac{x_{1}-\bar{x}}{s}
$$

Keterangan :

$\bar{x}$ adalah rata-rata dan s adalah simpangan baku sampel

2) Untuk setiap bilangan baku ini dan menggunakan daftar distribusi normal baku, kemudian dihitung peluang $\mathrm{F}\left({ }^{z_{i}}\right)=\mathrm{P}\left(z \leq{ }^{z_{i}}\right)$, jika nilai $Z$ negative maka nilai $F\left({ }^{z_{i}}\right)$ adalah $0,5-{ }_{\text {tabel }}$ jika nilai $Z$ positif maka nilai $F\left({ }^{Z_{1}}\right)$ adalah $0,5+{ }^{Z_{\text {tabel }}}$

3) Hitung proporsi ${ }^{z_{1}, z_{2}, z_{3_{\text {and }}} z_{n}}$ yang lebih kecil atau sama dengan ${ }^{z_{i}}$

4) Proporsi ini dinyatakan oleh $S\left({ }_{Z_{i}}^{z_{i}}\right)$

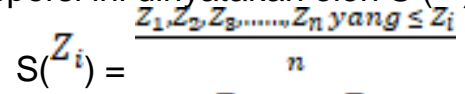

5) Hitung selisih $F\left({ }^{Z_{i}}\right)-S\left({ }^{Z_{i}}\right)$ kemudian tetukan harga mutlaknya

6) Ambil harga terbesar dari harga mutlak tersebut dan harga tersebut adalah ${ }^{L_{0}}$

7) Bandingkan ${ }^{L_{0}}$ dengan nilai krisil $L$ unuk uji liliefors dengan $\alpha=0,05$. Jika ${ }^{L_{0}}<{ }_{\text {tabel }}$ maka

$\mathrm{H}_{0}$ diterima artinya data berdistribusi normal (Sudjana,2005:467)

b. Uji Beda (t-test)

Setelah pengumpulan data selesai maka data-data tersebut akan dianalisis dengan uji

t. Uji untuk testing signifikan. Adapun rumus yang digunakan adalah sebagai berikut : 


$$
\mathrm{t}=\frac{M d}{s \sqrt{\frac{\sum X^{2} d}{N(N-1)}}}
$$

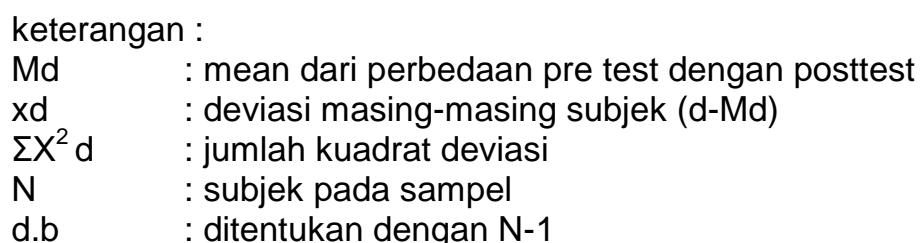

Hipotesis Uji-t

$\mathrm{H}_{\mathrm{o}} \quad\left(\mu_{1} \leq \mu_{2}\right)$ (Rata-rata nilai posttest tidak lebih atau sama dengan rata-rata nilai pretest)

$\mathrm{H}_{\mathrm{i}} \quad\left(\mu_{1}>\mu_{2}\right)$ (Rata-rata nilai posttest lebih dari rata-rata nilai pretest)

c. Uji ketuntasan belajar

Untuk mengetahui keefektifan pembelajaran digunakan kriteria ketuntasan belajar sebagai berikut:

1) Ketuntasan Belajar Individu (Perorangan)

Ketuntasan belajar siswa dapat dirumuskan sebagai berikut:

$$
\begin{aligned}
& \mathrm{KBI}=\frac{\text { jumlah nilainyang diperoleh siswa }}{\text { jumlah nilai maksimal selurwhnya }} \mathrm{x} \\
& 100 \%
\end{aligned}
$$

(Trianto, 2011: 241)

Apabila siswa telah menguasai sekurang-kurangnya $68 \%$ terhadap materi setiap satuan bahasan yang diajukan.

Ketuntasan individu $\geq 68$ Tuntas, indikator ketuntasan klasikal $\geq 80$ klasikal tuntas

2) Ketuntasan Belajar Klasikal

Di dalam pengukuran tuntas secara klasikal, dikatakan belajar tuntas dengan rumus:

$$
\mathrm{KBK}=\frac{\text { jumlah siswa yang tuntas belajar }}{\text { jumlah siswa yang mengikuti tes }} \times 100 \%
$$

Indikator ketuntasan klasikal $\geq 80$ klasikal tuntas

\section{Hasil dan Pembahasan}

Penelitian ini dilaksanakan di SD N 1 Sukodadi khususnya di kelas IV pada materi Keliling dan luas Bangun Datar. Sampel penelitian 32 peserta didik yang mengikuti pembelajaran dengan menerapkan metode Group Investigation. Dari hasil penelitian ini yaitu pengumpulan datanya menggunakan tes formatif soal pilihan ganda yang terdiri dari 40 soal uji

\begin{tabular}{|c|c|c|c|c|}
\hline Keterangan & \multicolumn{2}{|c|}{ Pretest } & & stest \\
\hline Nilai terendah & \multicolumn{2}{|c|}{26} & & 74 \\
\hline Nilai tertinggi & \multicolumn{2}{|c|}{74} & & 100 \\
\hline Rata-rata & \multicolumn{2}{|c|}{62,88} & & 9,03 \\
\hline Uji normalitas & \multicolumn{2}{|c|}{0,09} & & 0,13 \\
\hline Uji t & \multicolumn{4}{|c|}{21,74} \\
\hline & \multicolumn{2}{|c|}{$\mathrm{KBI}$} & \multicolumn{2}{|c|}{ KBK } \\
\hline Uji ketuntasan & $\begin{array}{l}\text { Pretest } \\
29,59 \%\end{array}$ & $\begin{array}{l}\text { postest } \\
41,90 \%\end{array}$ & $\begin{array}{c}\text { Prestest } \\
37,50 \%\end{array}$ & $\begin{array}{c}\text { Postest } \\
100,00 \%\end{array}$ \\
\hline
\end{tabular}
coba dan menjadi 23 soal yang valid untuk soal pretest dan posttest. Rekapitulasi dari Hasil belajar peserta didik dapat disajikan pada Tabel 6 sebagai berikut :

Tabel 7. Hasil Pengolahan Nilai Pre-Test dan Post-Test Peserta Didik 
Dilihat pada Tabel 6 hasil selisih nilai pretest tertinggi dan terendah berbeda. Nilai tertinggi pretest yaitu 74 , sedangkan terendah 26 . Nilai rata-rata pretest yaitu 62,88 . Hal tersebut menunjukkan bahwa nilai pada pretest masih rendah dan belum mencapai kriteria ketuntasan minimum (KKM) yaitu 68.Desain yang digunakan dalam penelitian ini adalah Pre Eksperimental Design dengan menggunakan One-Goup pretest-posttest Design. Data dari penelitian ini terdiri dari data pretest dan data posttest pada hasil belajar materi Keliling dan Luas Bangun Datar. Nilai dari hasil pretest sebagai pengukur kemampuan awal siswa dan nilai hasil posttest diambil dari hasil akhir setelah dilakukan pembelajaran menggunakan metode pembelajaran Group Investigation.

Perbandingan antara nilai pretest dan postest yang diperoleh pada akhir pembelajaran dan setelah dilakukan perlakuan Model Group Investigation mengalami kenaikan yaitu nilai tertinggi 100 dan terendah 74 dengan nilai rata-rata 89,0.

Setelah dilakukan analisis data nilai hasil belajar pada nilai pengetahuan diperoleh ratarata untuk pretest sebesar 62,88 dan postest 89,03 dengan $\mathrm{N}=32$ jadi $\mathrm{db}=\mathrm{N}-1=32-1=31$ yang diperoleh $t_{\text {hitung }}=21,74$ dengan taraf signifikan $5 \%$ di dapat nilai $t_{\text {tabel }}=1,6939$. Karena $t_{\text {hitung }}$ $21,74>t_{\text {tabel }} 1,6939$ maka $\mathrm{H}_{\mathrm{A}}$ diterima.

Pada hasil perhitungan Uji Ketuntasan pada pretest diperoleh $\mathrm{KBI}=29,59 \%$ dan $\mathrm{KBK}=$ $37,50 \%$ dengan KKM 68. Sedangkan hasil perhitungan uji ketutasan pada postest diperoleh $\mathrm{KBI}=41,90 \%$ dan $\mathrm{KBK}=100 \%$ dengan $\mathrm{KKM}$ 68. Sehingga dapat disimpulkan bahwa penerapan metode Group Investigation terhadap hasil belajar materi Keliling dan Luas Bangun Datar siswa kelas IV SDN 1 Sukodadi.

Penelitian ini dilaksanakan pada semester genap tanggal 16 sampai 17 April 2019 di SD N 1 Sukodadi Kecamatan Kangkung Kabupaten Kendal tahun pelajaran 2018/2019 pada siswa kelas IV dengan jumlah 32 siswa. Kondisi awal siswa sebelum dilakukan penelitian yaitu rendahnya nilai hasil belajar siswa pada pembelajaran matematika yang sebagian besar masih dibawah kriteria ketuntasan minimal (KKM).

Model pembelajaran Group Investigation seharusnya diberikan guru kepada siswa. Kejenuhan dalam pembelajaran dapat diminimalisir dengan penggunaan model pembelajaran yang baru. Penggunaan model pembelajaran tersebut tentunya akan dapat menarik perhatian siswa dalam menerima pembelajaran di kelas. Contoh model pembelajaran Group Investigation yang dapat menjadikan siswa lebih aktif selama mengikuti pembelajaran di kelas. Terlebih lagi pada pembelajaran Matematika yang menurut siswa menyatakan mata pelajaran yang sulit, sehingga model Group Investigation dapat mendukung pembelajaran untuk menunjukan kekonkritannya.

Kejenuhan pada siswa dapat dilihat dari hasil belajar yang kurang maksimal. Masih banyak siswa di SDN 1 Sukodadi Kendal yang mendapatkan nilai Matematika dibawah Kriteria Ketuntasan Minimal (KKM) yaitu sebesar 68. Hal ini dikarenakan guru saat mengajar masih menggunakan metode ceramah dan belum menerapkan variasi pembelajaran yang lebih menarik. Model pembelajaran Group Investigation merupakan salah satu jenis model pembelajaran dimana siswa diajak berpikir kemudian berdiskusi dengan kelompok untuk menyelesaikan masalah secara bersama untuk selanjutnya disampaikan kepada teman sekelas.

Untuk itu, peneliti melakukan penelitian di SDN 1 Sukodadi Kendal tahun Pelajaran 2018/2019. Sampel dalam penelitian ini diambil dengan non probability sampling dengan jenis sampling jenuh. Dalam penelitian ini subyek penelitian adalah siswa kelas IV dengan jumlah siswa 32 siswa. Penelitian ini menggunakan desain penelitian PreExperimental Desain dengan bentuk One Group Pretest-Posttest Design.

Hasil yang baik adalah apabila nilai Posttest lebih besar dari nilai Pretest. Berdasarkan hasil analisis uji coba instrumen, dengan mempertimbangkan validitas, reliabilitas, tingkat kesukaran, dan daya pembeda maka dapat didapatkan 23 soal memenuhi kriteria dari 40 soal uji coba instrumen. Kemudian 23 yang memenuhi kriteria tersebut digunakan untuk soal Pretest dan juga soal Posttest. Data awal penelitian menggunakan data dari nilai Pretest siswa. Ratarata nilai Pretest yaitu sebesar 62,88. Berdasarkan uji normalitas awal, data awal penelitian yang berasal dari nilai Pretest siswa adalah berdistribusi normal.

Hal tersebut dibuktikan dengan hasil $L_{\text {hitung }}$ sebesar 0,09 sedangkan $L_{\text {tabel }} 0,16$. Berarti $\mathrm{L}_{\text {hitung }} 0,09<0,16 \mathrm{~L}_{\text {tabel }}$. Rata-rata hasil Pretest yang diperoleh masih rendah dikarenakan proses pembelajaran yang berlangsung bersifat monoton. Belum digunakannya model pembelajaran sehingga siswa cenderung bosan untuk mengikuti pembelajaran. Data akhir penelitian menggunakan data dari Posttest siswa yaitu untuk mengetahui hasil belajar siswa 
setelah diberi perlakuan. Berdasarkan uji normalitas, data akhir penelitian dari nilai Posttest adalah berdistribusi normal.

Hal tersebut dibuktikan dengan $L_{\text {hitung }} 0,13<0,16 L_{\text {tabel }}$, maka $H_{0}$ diterima. Pada analisis akhir menggunakan uji t diperoleh hasil $t_{\text {hitung }}$ sebesar 21,74 sedangkan $t_{\text {tabel }} 1,69$ dengan $\mathrm{db}=$ $\mathrm{N}-1=32-1=31$, dan taraf signifikan 0,05. Karena $\mathrm{t}_{\text {hitung }}>\mathrm{t}_{\text {tabel }}$ yaitu 21,74>1,69 maka $\mathrm{H}_{\mathrm{o}}$ ditolak dan $\mathrm{H}_{\mathrm{a}}$ diterima. Sehingga dapat dikatakan bahwa model pembelajaran Group Investigation efektif terhadap hasil belajar siswa kelas IV SDN 1 Sukodadi Kendal.

Data nilai uji ketuntasan belajar siswa pada KBI (Ketuntasan Belajar Individu) untuk Pretest yaitu sebesar 29,59\% sedangkan uji KBI (Ketuntasan Nilai Individu) pada Posttest yaitu 41,90\%. Dan untuk uji ketuntasan KBK (Ketuntasan Belajar Klasikal) pada Pretest yaitu sebesar $37,50 \%$ sedangkan uji KBK (Ketuntasan Belajar Klasikal) pada Postest yaitu sebesar 100,00\%. Berdasarkan uraian di atas dapat diketahui bahwa pembelajaran dengan menggunakan model Group Investigation efektif terhadap hasil belajar siswa.

Hasil penelitian menunjukan bahwa penggunaan model Group Investigation juga membantu guru dalam mengelola kelas selama pembelajaran berlangsung. Hal ini dikarenakan siswa lebih tertarik, merasa senang serta dapat mendukung dan membantu keaktifan aktif selama proses pembelajaran. Hal ini menunjukan bahwa model Group Investigation efektif terhadap hasil belajar siswa kelas IV khususnya pada mata pelajaran Matematika materi Keliling dan Luas Bangun Datar. Hasil penelitian ini sesuai dengan hasil penelitian yang didapatkan oleh Erlinawati dan H. Marhadi (2013) yang menyebutkan bahwa model pembelajaran group investigation dapat meningkatkan hasil belajar IPS dan dapat meningkatkan kualitas pembelajaran siswa. Berdasarkan penelitian tersebut, penggunaan model pembelajaran kooperatif tipe group investigation dalam pembelajaran telah menunjukkan hasil yang positif.

Selain itu, dari hasil nilai Posttest menunjukan bahwa hasil belajar siswa meningkat dari sebelumnya yaitu nilai Pretest. Pelaksanaan penelitian ini diberikan Pretest diawal pembelajaran untuk mengetahui pengetahuan siswa (kognitif), setelah itu peneliti memberikan perlakuan (treatment) dengan menggunakan model pembelajaran Group Investigation.

Model pembelajaran Group Investigation dapat membuat siswa senang saat mengikuti proses pembelajaran, karena model ini siswa dapat berdiskusi dalam pembelajaran. Dikemukakan juga oleh Suprijono (2011) bahwa dalam penggunaan model Group Investigation, setiap kelompok akan bekerja melakukan investigasi sesuai dengan masalah yang mereka pilih. Sesuai dengan pengertian-pengertian tersebut, diketahui bahwa model Group Investigation adalah pembelajaran yang melibatkan aktifitas siswa sehingga tentu akan membangkitkan semangat serta motivasi mereka untuk belajar (Shoimin, 2014:80).

\section{Simpulan dan Saran}

Penerapan model pembelajaran dengan Group Investigation di SDN 1 Sukodadi berjalan sesuai dengan langkah-langkah yang sudah ditentukan. Model Group Investigation efektif digunakan pada mata pelajaran Matematika siswa kelas IV SDN 1 Sukodadi. Keefektifan model Group Investigation dapat dilihat dari perbedaan hasil belajar Pretest dan Posttest. Uji perbedaan rata-rata Posttest menunjukan sebesar 21,74..

Adapun saran yang dapat penulis sampaikan yaitu: Model Pembelajaran Group Investigation diterapkan dalam pembelajaran di sekolah untuk meningkatkan hasil belajar siswa. Terutama untuk materi perhitungan sebagai solusi untuk memudahkan siswa dalam memahami rumus-rumus Matematika. Peran guru sebagai fasilitator, motivator dan lingkungan pembelajaran yang menyenangkan diperlukan siswa untuk mengoptimalkan belajar mandiri dan mengembangkan pengetahuannya. Sebelum menerapkan model pembelajaran Group Investigation, guru terlebih dahulu membuat perencanaan pembelajaran yang akan dilaksanakan sesuai dengan sintak model Group Investigation agar pelaksanaan proses pembelajaran akan berlangsung dengan sebagaimana mestinya.

\section{Daftar Pustaka}

Arif Arikunto, Suharsimi. 2010. Prosedur Penelitian Suatu Pendekatan Praktik. Jakarta. Rineka Cipta

Ayu, Andhika Wulandari. 2010. Efektifitas Penggunaan Metode Group Investigation dan Brainstrming terhadap Prestasi Belajar Matematika Siswa Kelas V Sekolah Dasar 
Negeri Se-Kecamatan Laweyan Pada Pokok Bahasan Sifat-Sifat Bangun Datar Ditinjau Dari Aktifitas Belajar Siswa. Tesis. Universitas Sebelas Maret Surakarta.

Darmadi. 2017. Pengembangan Model dan Metode pembelajaran dalam Dinamika Belajar Siswa. Yogyakarta. Group Penerbit CV BUDI UTAMA

Depdiknas. 2003. Sistem Pendidikan Nasional. Jakarta. Departemen Agama.

Erlinawati dan H. Marhadi 2014. Penerapan Model Pembelajaran Kooperatif Tipe Group Investigation untuk Meningkatkan Hasil Belajar IPS Siswa Kelas IV SD Negeri 56 Pekanbaru. Primary, Volume 3, Nomor 1 (hal 9-14).

Fathurrahman. 2015. Model-Model Pembelajaran Inovatif. Yogyakarta. Ar-Ruzz

Hanisah, Siti, S Tri, B setyo. 2014. Penggunaan Model Pembelajaran Kooperatif Tipe Group Inestigation Dalam Peningkatan Pembelajaran Matematika tentang Pecahan Pada Siswa Kelas V SD. Jurnal Kalam Cendekia. 2 (2):5-7.

Huda, Miftahul. 2013. Model-Model Pengajaran dan Pembelajaran. Yogyakarta. Pustaka Pelajar.. Cetakan kedua, September 2013

Isrok'atun, Amelia Rosmala. 2018. Model-Model Pembelajaran Matematika. Jakarta. PT Bumi Aksara.

Juwariyah, Siti. 2013. Penggunaan Metode Group Investigation Untuk Meningkatkan Keaktifan Belajar dan Hasil Belajar Siswa Pada Mata Pelajaran Matematika di Kelas IIIA SDIT Arofah 2 Klego Tahun Ajaran 2012/2013. Jurnal Ilmiah. Universitas Muhammadiyah Surakarta.

Rusman. 2017. Belajar dan Pembelajaran Berorientasi Standar Proses Pendidikan. Jakarta. Kencana

Shoimin, Aris. 2014. 68 Model Pembelajaran Inovatif. Yogyakarta. Ar-Ruzz Media

Slameto. 2013. Belajar Dan Faktor-Faktor Yang Mempengaruhinya. Jakarta. Raneka Cipta

Suardi, Moh. 2018. Belajar Dan Pembelajaran. Yogyakarta. CV Budi Utama

Sudijono, Anas. 2009. Pengantar Statistik Pendidikan. Jakarta. PT RajaGrafindo Persada.

Sugiyono. 2012. Statistika Untuk Penelitian. Bandung. Alfabeta

2017. Metode Penelitian Pendidikan. Bandung. ALFABETA CV

Suprijono, Agus. 2012. Cooperative Learning. Yogyakarta. Pustaka Pelajar

Susanti, Yusi., dkk. 2013 Pengaruh Model Pembelajaran Kooperatif Tipe Groupp Imvestigation Berdasarkan Keterampilan Proses terhadap Hasil Belajar IPA Siswa Kelas IV SD Gugus 2 Mengwi. Mimbar PGSD Undiksha, Volume 1, Nomor 1.

Susanto, Ahmad. 2013. Teori Belajar \& Pembelajaran. Jakarta. PRENADA MEDIA GROUP

Syaodih, Sukmadinata Nana. 2010. Metode Penelitian Pendidikan. Bandung. PT Remaja Rosdakarya.

Trianto, 2010. Mendesain Model Pembelajaran Inovatif - Progresif : Konsep, Landasan, dan Implementasinya pada Kurikulum Tingkat Satuan Pendidikan (KTSP). Jakarta. Kencana Penada Media Group. 
Uliya, Nuhyal. 2016. Peningkatan Pemahaman Konsep Matematika Materi Bangun Datar dengan Pembelajaran Kooperatif Tipe Group Investigation dengan Pendekatan Staintifik di SD. Jurnal Tunas Bangsa. 3(2) : 64-65.

Yasin, Ahmad. 2016. Penerapan Metode Kooperatif Model Group Investigation Sebagai Alternatif Meningkatkan Hasil Belajar Matematika Pokok Bahasan Hubungan Antar Satuan Berat Pada Siswa Kelas IV Semester II SDN 3 TlogosariTahun Pelajaran 20142015. Jurnal Pancaran. 5(4) : 31-50. 